\title{
Last Reported Free
}

National Cancer Institute

\section{Source}

National Cancer Institute. Last Reported Free. NCI Thesaurus. Code C159697.

An indication of the last noted time an individual was without something. 